\title{
BALTAZAR HACQUET (1739/40-1815), THE PIONEER OF KARST GEOMORPHOLOGISTS
}

\author{
BALTAZAR HACQUET (1739/40-1815), PIONIR \\ V GEOMORFOLOGIJI KRASA
}

\author{
Andrej KRANJC ${ }^{1}$
}

\begin{abstract}
UDC 551.44 : 929 Hacquet B.

Andrej Kranjc: Baltazar Hacquet (1739/40-1815), the Pioneer of Karst Geomorphologists

Besides other sciences, B. Hacquet dedicated his research to geology and geomorphology (as we call them now). His most important work "Oryctographia carniolica or Physical (= geological) description of Carniola..." (1778-1789) contains descriptions of rocks, ores, fossils, as well as surface and underground features. In Carniola, karst is prevailing and therefore there is a lengthy description of karst geology and geomorphology included. His classification of mountains specially mentions Montes secundarii formed by grey limestone. Of surface features dolines, glacio-karstic dolines on high plateaus (with temperature and vegetation inversion), and karst poljes are mentioned. Hacquet presumed the evolution from flooded polje (seasonal lake) to a dry one. To explain the weathering and dissolution of limestone Hacquet took into account the differences between the rock, the exposition and its element content. That is the reason why Gams regarded him as a precursor of a climatic geomorphology and the "father" of corrosion theory. Hacquet has also found the difference between limestone and dolomite. His description of dolomite as Lapis suillus preceded the one of D. Dolomieu for 13 years. Hacquet's statements were not based on observation only, but on the experiment too. When looking upon Hacquet's explanations and results we must not forget that Hacquet's time was still time of parapathetic logic, of four elements and of the principle of burning - the flogiston.
\end{abstract}

Key words: history of geomorphology, karstology, Hacquet B., Carniola, Slovenia.
Izvleček UDK 551.44: 929 Hacquet B. Andrej Kranjc: Baltazar Hacquet (1739/40-1815), pionir $v$ geomorfologiji krasa

Poleg drugih znanosti se je B. Hacquet posvečal tudi geologiji in geomorfologiji, kot ju imenujemo danes. Njegovo najpomembnejše delo "Oryctographia carniolica ali Fizični (= geološki) opis Kranjske...” (1778-1789) vsebuje opise kamnin, rudnin, fosilov kot tudi površinskih in podzemeljskih oblik. $\mathrm{Na}$ Kranjskem prevladuje kras in $\mathrm{v}$ svoje delo je vključil tudi dolg opis geologije in geomorfologije krasa. V razvrstitvi gora je posebej pozoren na Montes secundarii iz sivega apnenca. Od površinskih oblik omenja vrtače, na visokih planotah konte $(\mathrm{z}$ rastlinskim obratom) in kraška polja. Domneva, da so se kraška polja razvijala od poplavljenih (presihajočih jezer) do suhih polj. Da bi razložil preperevanje apnenca je Hacquet upošteval razlike $\mathrm{v}$ kamnini, osončenost in vsebnost elementov. Zaradi tega ga Gams šteje za začetnika klimatske geomorfologije in za »očeta" teorije korozije. Hacquet je odkril tudi razliko med apnencem in dolomitom. Njegov opis dolomita pod imenom Lapis suillus je izšel 13 let preden je objavil svojega D. Dolomieu. Hacquet ni sklepal le na podlagi opazovanj, ampak tudi na podlagi poizkusov. Ko gledamo na Hacquetove razlage in izsledke, ne smemo pozabiti, da je bila čas, v katerem je živel, še čas parapatetične logike, štirih elementov in principa gorenja - flogistona.

Ključne besede: zgodovina geomorfologije, krasoslovje, Hacquet B., Kranjska, Slovenija. 


\section{INTRODUCTION}

Baltazar (Balthazar, Belsazar) Hacquet was born in France 1739 or 1740 and died at Vienna in 1815 . He spent the period from 1766 to 1787 in Carniola. During the first years he was a surgeon at Idrija mercury mine. During later years he hold different positions at Ljubljana, such as the secretary of the Agricultural Society and the professor of chemistry and obstetrics. Finally he left "bigoted and uncultured" Carniolians and took the offer of the University at Lvov (Lviv) to become professor of natural history and medicine there (Gauchon 1999) (Fig. 1).

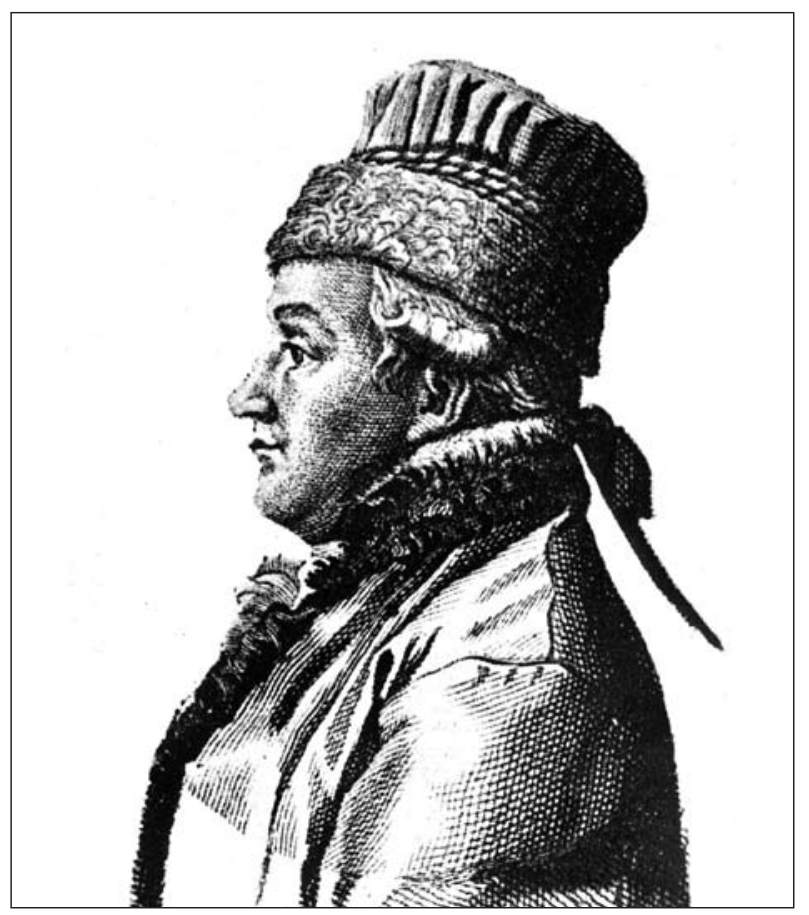

Fig. 1. Baltazar Hacquet (Ilustrirani Slovenec 1927).

Besides medicine as his professional occupation, he was very interested in other sciences, mainly in chemistry, palaeontology with mineralogy, hydrology, and speleology, not to mention medicine, ethnography etc. In his works he often presented himself as being a chemist. He initiated new chemistry theories and introduced the methods of quantitative and qualitative chemical analyses to Carniola (Tišler 2003). He dedicated a great part of his free time to study and work in science. But travels attracted him the most, either walking around Idrija on a nice Sunday afternoon or travelling across Dinaric or Carpathians Mountains. Long distance travels, mostly through the mountains of Central, Southern and Eastern Europe took him two months per year in average. Not sport but scientific motives forced him to climb the mountains thus becoming very important person in the history of mountaineering. I must mention that he was a member of the second team who succeeded to reach Triglav $(2864 \mathrm{~m})$, the highest peak of Julian Alps. It is due to a bad weather that prevented him to be the first one (Lovšin 1946).

Hacquet published a lot, his bibliography contains 110 articles in scientific journals and about 30 books and extensive treatises as well (Valjo 1997). He wrote about the results of his observations and experimental work (even about an ice frost on his window panel) (Južnič 2003) as well as detailed accounts of his travels. To illustrate them he added maps drawn by himself. He published the first geological map of Carniola (a great part of present Slovenia). His principle to put on maps the names used by local population (in "local" language) is important for Slovenia - on his geological map there are Slovene names of places and not German ones as was the habit in Hacquet's time. It seems that Hacquet was the first to use the name "Dinaric Alps" roughly in the sense of nowadays Dinaric Mountains (Hacquet 1778 - 1789) (Fig. 2).

From the point of view of karstology his the most important work was "Oryctographia carniolica oder Physikalische Erdbeschreibung..." that is the "Physical Description of the Duchy of Carniola, Istria and part of neighbour countries", written in German language (Hacquet $1778-1789$ ). It was published in four volumes, printed in Leipzig by J. G. I. Breitkopf between 1778 and 1789 . The work has over 700 pages in total. In Hacquet's time physical description meant primarily geology and geomorphology, but a lot of work is dedicated to economy, mines and specially mining industry.

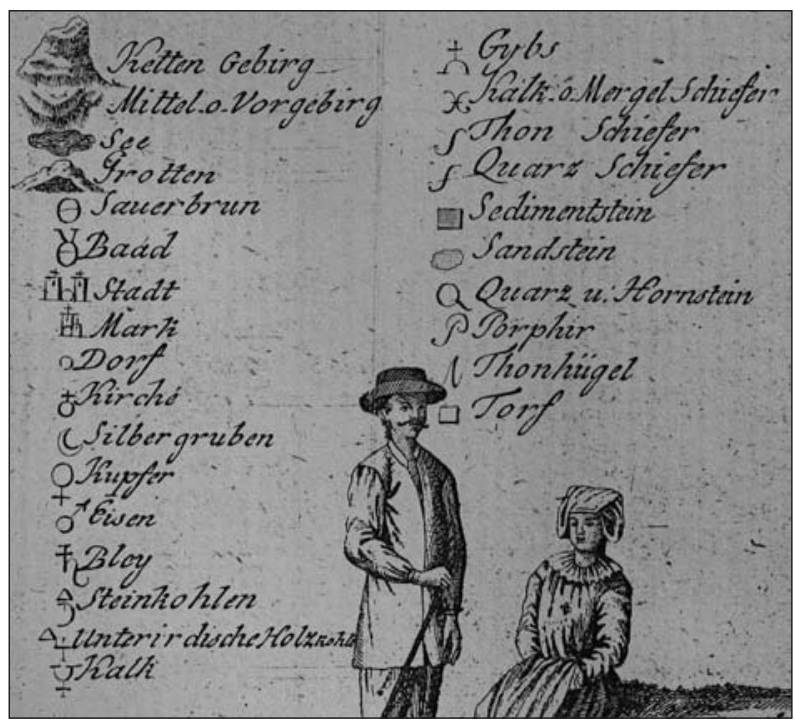

Fig. 2. Cutting out of the legend to Hacquet's Mappa Litho Hydrographica Nationis slavicae (Hacquet 1778 - 1789). 


\section{GEOMORPHOLOGY IN HACQUET'S TIME}

"So little progress (in the field of geomorphology, note by the author) was made in Europe from the days of the first century A.D. until the opening of the sixteenth century that little need to be said about it " (Fenneman 1939). During the $15^{\text {th }}, 16^{\text {th }}$, and $17^{\text {th }}$ centuries land forms were explained largely in terms of the then-prevailing philosophy of catastrophism, according to which the features of the Earth were either specially created or were the result of violent cataclysms which produced sudden and marked changes on the surface of the Earth. As long as the Earth's age was measured in a few thousands years, there was not much chance for the importance of slow geologic processes to be appreciated (Thornbury 1969). Some of the Hacquet's ideas on geomorphology correspond to the general knowledge prevailing in the $18^{\text {th }}$ century.

Hacquet's contemporaries were so called "pre-Huttonian" geomorphologists. The most important among them were Jean Étienne Guettard (1715 - 1786), Nicolas Desmarest (1725 - 1815) and Horace Benedict De Saussure $(1740$ - 1799). They, perhaps more than any others paved the way for Hutton (1726-1797) (Thornbury 1969). James Hutton himself lived at the same time as Hacquet. But his The Theory of the Earth was published too late (1785) to be possible for Hacquet to use it. Being a dense and borderline unreadable work it was not perceived by the science circles before the simplified version by Playfair (1802). Modern geomorphology started by Hutton's ideas and developed in the second part of the $19^{\text {th }}$ century. It appears that the term "geomorphology" was used in its present sense by Keith as long ago as in 1894 (Thornbury 1969), while others stated that the term was first mentioned by Naumann in 1858 already (Herak \& Stringfield).

In his Oryctographia Hacquet cited about 190 authors. Among them are well known old authors as Aristoteles, Democritus, Herodotus, Posidonius, Thales, and Plinius. He cited some works of his well known contemporaries, Beckmann (1776), Collini (1774), Gruber
(1781), and Leroy (1776), just to mention some examples. Among the cited authors are well known authorities previous to Hacquet as Agricola, Buffon, Kircher, Leibnitz, and Linné. From the science of chemistry, mineralogy and geology Hacquet used the works of Boerhave, Born, Boyle, Delisle, Lavoisier, Sage, Scheele, and Wallerius among others less known nowadays. He was acquainted with the theories of his time about the Earth by the authors Bertrand, Burnet, Whiston and Woodwart. It is self-understanding that he knew the works treating the nature of Carniola and other nearby countries, for example Brown, Cluverus, Fortis, Gruber, Kircher, Schönleben, Scopoli, Steinberg and Valvasor.

Although Hacquet knew and used the works of his contemporaries, the scientists who founded a modern science, like Boyle and Lavoisier, his scientific knowledge corresponds to the knowledge of his time. Agricola's classification of minerals from 1556 was still in use. For example: mineral bodies were divided into inhomogeneous and homogenous bodies; the last containing simple minerals. And simple minerals were: earths, solified juices, stones, and metals. To explain different rates of solution of limestone and dolomite Hacquet helped himself by flogiston - the principle of burning.

In Oryctographia Hacquet cited and discussed Guettard's paper in "Mémoires de l'Academie Royale des Sciences" (1746-1764) on the types of "Tropfsteine" (speleothems). He appreciated very much DE Saussure's "Voyage dans les Alpes" (1777-1796). Regarding the fact that Hacquet only had the first two volumes of De Saussure's book and that the manuscript of the last volume of Oryctographia was completed in 1787, he could not be acquainted with De Saussure's views upon limestone Alps, which interested Hacquet the most: "...so hoffe ich auch, Herr von Saussure wird ... die grosse Kalkalpkette der Schweiz nicht übergehen..." (...so I hope that Mr. Von Saussure will not omit the great Alpine limestone range in Switzerland...).

\section{HACQUET'S VIEW ON KARST MORPHOLOGY}

Not only in "Oryctographia carniolica" the karst was mentioned but also in other Hacquet's books about his travels through Austrian and Turkish Illyrien, through Eastern Alps (from Triglav to Grossglockner), through Southern Alps (from Dinaric to Noric Alps) and through Carpathians.
In accordance with some other authors Hacquet classified the mountains into three types: Montes primarii - Hauptgebirge (the main range) of primary rocks; Montes secundarii - Mittelgebirge (middle mountains) of Lapis calcarius, the grey limestone; Montes tertiarii Vorgebirge (fore mountains), product of weathering. But 
Hacquet stressed that also limestone mountains can be of the same importance as the Montes primarii and that some middle mountains of limestone have the scree of limestone debris only, without marl (Fig. 3).

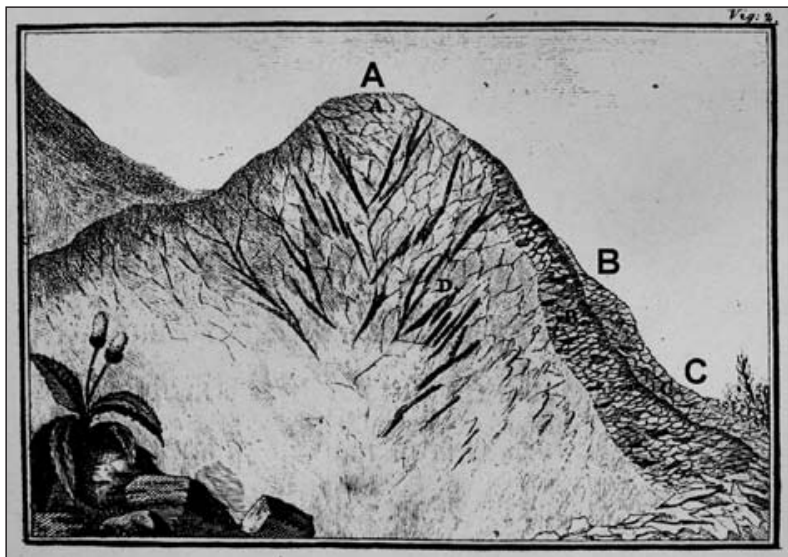

Fig. 3. Hacquet's illustration to Montes secundarii - Mittelgebirge of Lapis calcarius (Grey limestone). A - Grauer Kalkfels (Grey limestone rock), B - Schieferanlage (Shale complex), C Kalktrümmeranlage (Limestone debris complex) (Hacquet 1778 - 1789).

Hutton's (1785) book on the evolution of the Earth and his famous statement "No vestige of a beginning - no prospect of an end" were not known by Hacquet as this book was published much later than "Oryctographia". In contrast to most of Hacquet's contemporaries, Hacquet clearly was not a "catastrophist". In nature, in landscape Hacquet saw a demonstration of slow relief evolution. For the illustration just few examples from "Oryctographia":

- Plateau Kras (Karst, Carso) was once a big lake or part of a sea, a bay of the Adriatic Sea. The ridges and summits of Dinaric Alps were a chain of islands, as are nowadays the islands along the coast, from Istria to Ragusa (Dubrovnik).

- The bottom (its features and the sediments) of the polje Dobrepolje proves that the polje was once a lake closed by limestone mountains, which drained and finally became dry.

- Levelled surfaces in the mountains, for example around the Snežnik Mountain, are due to the effect of rain.

- Terraces of the valley of Žejane (Istria) are the proof that once the valley bottom was higher than nowadays.

As for karst morphology Hacquet often mentioned bare rocky karst surface and its ability to absorb immediately all the meteoric water. He compared the region Kras (Karst) with the rocky Arabia petrea. Karst (closed) depressions specially attracted his attention, such as deep dolines and poljes. The first he calls Kessel (kettle) or Vertiefungen (deepening) and the second Kesselthal (kettle valley) or geschlossene Fläche (closed plain). He was specially impressed by great "Kessel" on high karst plateaus. In them Hacquet observed vegetation inversion. Today we call this form "konta" - a glacio-karstic doline. It is clear that he devoted a special attention to the polje of Cerknica or Cerkniško Jezero (lake) (Fig. 4).

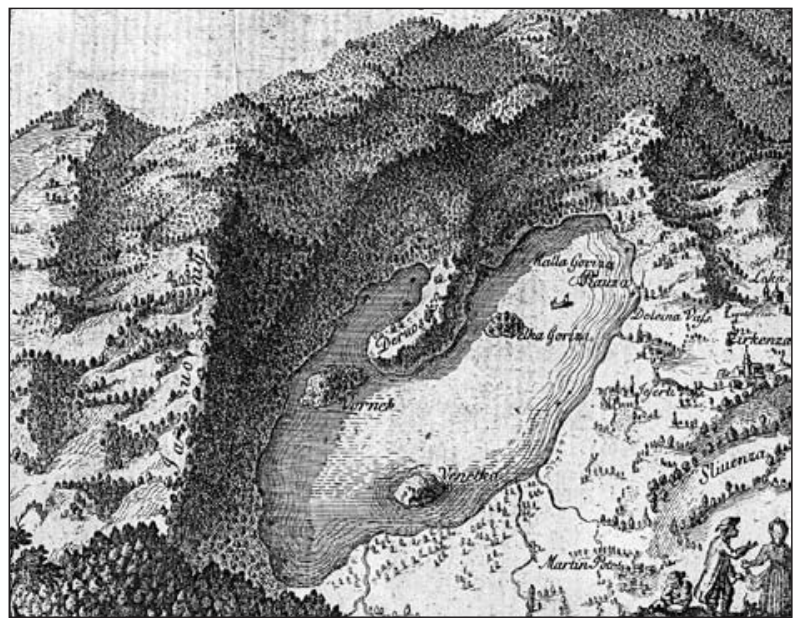

Fig. 4. Hacquet's panorama of Cerkniško Polje (Hacquet 1778 1789).

Hacquet paid a special attention to the weathering of limestone. He found out that the irregular weathering is due to unhomogeneity of limestone. He established this by a test by "mineral acid". He observed different intensity of weathering regarding the side of the slope: on the sunny side rocks are more weathered than on the shady side. He explained this by different intensity of calcination. In the heat the limestone calcinates stronger and the product, the calx is washed away by rain. Hacquet also knew that the limestone weathered first into clay-shale and finally into clay. The idea and the terms calx and calcination go back to Agricola. In modern terms they mean oxide and oxidation.

Maybe more than by the features which are a result of dissolution of limestone, Hacquet was interested in the process itself, in solution of limestone. By the general knowledge of the time the minerals and rocks contain the following components:

fixe Luft (fixed air) or Luftsäure (much later J. Black found out that "fixed air" is in fact CO2), Elementarerde (elementary earth), and fixe Feuer or Flogiston. According to Hacquet's ideas all bodies contain fixe Luft and fixe Feuer (Flogiston). Elementarerde which is never in pure form, is also in limestone. Regarding Flogiston, it was Lavoisier who proved that it does not exist.

Hacquet's views upon the dissolution of limestone can be resumed as follows: 
- water dissolves limestone with the help of acid,

- dissolved limestone remains in water to be deposited later,

- water cannot dissolve dolomite because of the Flogiston.

The acid, which helps to dissolve limestone, is only one, Acidum universale, but it can exist in different forms. In the air there can be also other acids and alkalines, such as saline rain. Also calx may contain Acidum universale. And essential for the dissolution is Luftsäure/Elementarerde ratio. The process of dissolution has the following course: acid dissolves limestone by taking away essential parts of calx (fixe Luft or Luftsäure) and clay remains.

Opposite of dissolution is deposition, in this case deposition of calcite: water dissolves limestone, takes it into the cave and deposits it in the form of Tropfsteine (speleothems) or vielfältige Steinrinden or incrustationes (crust) (Kranjc 2003).

Hacquet is also important for geomorphology and geology because of his study of dolomite. In 1778 he described the dolomite for the first time as a rock different from limestone. It was 13 years before D. De Dolomieu (1791) published his basic paper "Sur un genre de pierre calcaires très peu effervescentes..." on the rock, which was later named after him. It has to be mentioned that Dolomieu visited Hacquet while travelling through Ljubljana. It was before the publication of the mentioned paper. Hacquet called dolomite Stinkstein (Lapis suillus), this is "stinking stone". He found out that water cannot dissolve a lot of dolomite - because of Flogiston. And therefore such water does not deposit flowstone or speleothems in caves. He observed such a situation in Podpeška Jama cave at the polje of Dobrepolje. The plan of this cave was already published by Valvasor in 1687 .

The essential problem which has to be solved to explain the dissolution of limestone, or the process of corrosion as we say today, was according to Hacquet's opinion the following: Where does the acid which dissolves limestone come from? Does it come from the air (Vitriolsäure) or does it form from the Luftsäure which is one of substantial components of limestone itself?

\section{CONCLUSION}

For the conclusion I have to repeat the most important observations, ideas and revelations achieved by Baltazar Hacquet in the field of geomorfology and karstology:

- he explained the evolution of the relief by slow and continuous action of exogene forces instead of catastrophes;

- he tried to explain weathering of limestone;

- he discussed and tried to explain differential dissolution of limestone;
- he described the most important karst features (dolines, poljes, caves);

- he described the dolomite and drew the distinction between it and limestone (before De Dolomieu);

- he stressed the importance of limestone mountains.

\section{ACKNOWLEDGMENT}

The research was carried out in the frame of the programme "Karst research" funded by the Slovenian Re- search Agency and supported by the Slovene Science Foundation. 


\section{REFERENCES}

Anon., 1927: Hacquet Baltazar (1739 - 1815), part. chir., naravoslovec.- Ilustrirani Slovenec Vol. 3, No. 38, p. 314

Dolomieu, D. d., 1791: Sur un genre de pierres calcaires très peu effervescentes avec les acides et phosphorescentes par la collision.- J. Physique 39, 3-10

Fenneman, N. M., 1939: The rise of physiography.- Bull. Geol. Soc. Am. 50, 349-360

Gauchon, C., 1999: Investigations about Balthazar Hacquet.- Slovenský kras 37, 53-60

Guettard, J. E., 1746 - 1764: Mémoires de l'Academie Royale des Sciences. - In: http://www.cosmovisions. com/Guetard.htm

Hacquet, B., 1778 - 1789: Oryctographia Carniolica oder Physikalische Erdbeschreibung des Herzogthums Krain, Istrien, und zum Theil der benachbarten Länder. - Erster Theil (1778): XVI, 162 pp., Zweyter Theil (1781): XXXII, 186 pp., Dritter Theil (1784): XX, 184 pp., Vierter Theil (1789): XVI, 91 pp., G. I. Breitkopf, Leipzig

Hacquet, B., 1785: Physikalisch-politische Reise aus den Dinarischen durch die Julischen, Carnischen, Rhätischen in die Norischen Alpen im Jahre 1781 und 1783 unternommen von Hacquet.- 2 Th.: 156 and $220 \mathrm{pp}$.

Herak, M. \& V. T. Stringfield, 1972: Karst - important karst regions of the Northern Hemisphere.- Elsevier. XIV, $551 \mathrm{pp}$.
Hutton, J., 1785: Theory of the Earth.- In: http://www.answers.com/topic/james-hutton, 11.8.2005

Južnič, S., 2003: Ledene rože na Hacquetovem oknu. Hacquetia. Vol. 2, No. 2: 119-128

Kranjc, A., 2003: Balthasar Hacquet, predecessor of modern karstology.- Hacquetia, Vol. 2, No. 2: 129-138

Lovšin, E., 1946: V Triglavu in njegovi soseščini.- Ljubljana, 358 pp.

Naumann, C. F., 1858: Lehrbuch der Geognosie.- Engelmann, Leipzig, 576 pp.

Playfair, J., 1802: Illustrations of the Huttonian Theory of the Earth.- In: http://www.answers.com/topic/ james-hutton, 11.8.2005.

Saussure, B. H. de, 1777 - 1796: Voyage dans les Alpes.In: "Horace Benedict de Saussure." LoveToKnow 1911 Online Encyclopedia. 2003, 2004 LoveToKnow, http://42.1911 encyclopedia.org/S/SA/SAUSSURE_ HORACE_BENEDICT_DE.htm

Thornbury, W. D., 1969: Principles of Geomorphology. John Willey \& Sons, 594 pp.

Tišler, M., 2003: Prispevki kemije k evropski kulturi in civilizaciji.- Dela - Opera 13, Classis III, SAZU, Ljubljana, 170 pp.

Valjo, M., 1997: Baltazar Gaket i Ukraina.- Lvivska naukova biblioteka, Lviv, 133 pp. 